\title{
Crime, Self-Protection and Business Growth in Cote d'Ivoire
}

\author{
Assi José Carlos Kimou \\ Felix Houphouet-Boigny University, Abidjan, Ivory Coast \\ Email: assikimou@gmail.com
}

Received 27 August 2015; accepted 27 October 2015; published 30 October 2015

Copyright (C) 2015 by author and Scientific Research Publishing Inc.

This work is licensed under the Creative Commons Attribution International License (CC BY). http://creativecommons.org/licenses/by/4.0/

(c) (i) Open Access

\begin{abstract}
Cote d'Ivoire was considered as an island of stability and economic prosperity in a region of stagnation, and political turmoil. The situation was reversed in the early 2000 , when a decade of instability led to a surge in crime and violence. Yet, very little was known about the economic consequences of crime at the firm level. This paper tested empirically the impact of crime on business activity in Cote d'Ivoire. Using a recent World Bank enterprise survey dataset and a Heckman two-step procedure we showed that crime and private provision of security negatively impacted firms' profit and investment.
\end{abstract}

\section{Keywords}

Crime, Private Protection, Business, Post-Conflict, Cote d'Ivoire

\section{Introduction}

In the immediate period after independence, Cote d'Ivoire was considered as an island of stability and economic prosperity in a region of radical economic ideologies, stagnation, and political turmoil. The situation was reversed in the late 1990s, when a coup d'état, repeated coup attempts, a series of violent clashes ultimately resulted in a civil war in 2002 (Akindes, 2002). This decade of instability was associated with poor economic performance, breakdown of law and order, increased violent crime, and a deterioration of business environment as recorded in most international governance reports. The Mo Ibrahim Governance Report on Africa was ranked Cote d'Ivoire 46th out of 53 countries in 2011 and the country was ranked 170th out of 183 worldwide in the World Bank’s 2011 Doing Business Report.

Kimou [1] showed that possession of illegal firearms increased noticeably in this period and the average counts of aggravated assaults increased by $100 \%$ compared to a decade earlier. The Ivorian Chamber of Commerce reported that in 2004, more than 10,000 jobs were lost and 100 enterprises closed following violent dem- 
onstrations, harassment, violence, and aggravated assaults. That phenomenon was coupled with poor enforcement of the law and inefficient judicial system with estimated ratios of policeman per inhabitant and judge per inhabitant respectively of $1 / 1500$ and of $1 / 40,000$ to create a climate of fear and uncertainty.

Increased crime rate in Cote d'Ivoire may affect the dynamics of the private sector either by impeding the inflows of foreign direct investment (FDI) due to higher country risk, by harming the performance of existing firms, or preventing new and existing domestic firms from expansion because of increased cost of production. The increasing crime rate in a context of decreased police protection may drive firms to purchase protective services in order to decrease losses from crime. What are the firms that are likely to self-protect under these circumstances? Does crime decrease firm level investment? What is then, the effect of crime and self-protection on business profitability?

This paper investigates how business firms have been affected by crime especially in a post-conflict context. We use a recent World Bank enterprise survey data for Cote d'Ivoire, and a Heckman two-procedure to investigate the issue of crime and self-protection in Cote d'Ivoire. The main hypothesis we test is that crime costs generated self-protection significantly affect the dynamics of business. We measure business growth in two different ways-accounting profit and volume of investment.

Cote d'Ivoire is going through a post-conflict reconstruction and one of the main ways to achieve a sustained peaceful reconstruction is to achieve a rapid and sustained long-term economic growth. The private sector is essential in this reconstruction through job creation and poverty reduction. This private sector led reconstruction can be derailed by increased crime. Yet, very little is known about the effects of crime and violence on private sector activity in Cote d'Ivoire even though it may be important in the development of the private sector.

This paper is a contribution to the effects of crime on business activities in Cote d'Ivoire. We perform the parametric two-step Heckman model for selection bias correction to account for the economic impact of criminal activities in a context of government inefficiency.

The issues of crime, instability and institution nexus for economic development in Africa have been moderately researched. While some papers investigate either the cause and consequences of crime on both individual and society [1]-[3] or on the microeconomic and macroeconomic impacts of institutions and instability on business sector in sub-Saharan Africa [4]-[7], very few have studied how firms operating in post-conflict countries are affected by high crime rates and security threat generally. Our main results can be summarized as follow: Crime affects negatively the performance of businesses operating in Cote d'Ivoire during the period of political turmoil through perceived crime and self-protection by not only reducing profitability but hampering investment as well.

The remainder of the paper is structured as follows: The next section presents the literature review; Section 3 presents a brief overview of crime and private sector trends in Cote d'Ivoire, Section 4 describes the methodology we use to estimate the effect of crime and disorder on business growth. Section 5 presents the results and provides some policy discussions. Section 6 concludes the paper.

\section{Literature Review}

The negative externally caused by crime has been moderately addressed in the literature. Many authors have pointed out the negative impact of crime either on economic growth (Rubio, 1996), poverty [3], human capital investment (Fajnzylber, et al., 1996) or on social capital formation (Glaeser, et al., 1996, 1999). The World Bank [8] points out the negative effect of crime on governance. However, inquiry on the economic consequence of crime and violence at the firm level is becoming of great interest, even though it is yet to be studied in many contexts.

Bates and Robb [9] investigate the effects of crime rate on firm performance at different locations and conclude that the effect of crime on firm performance might be undetermined. If low crime areas offer higher returns than high crime areas, investments should be driven to high crime area locations until returns are equalized across all locations. If high-crime locations are riskier than low-crime areas, investments flows should be driven towards the high-crime area, only if firms operating in that area earn above-average profits that exceed the cost of crime because of the disutility or decreased production up to a point where expected returns to capital are equalized across the two areas.

Using survey data on business owners in the United States, multivariate analysis, and taking into account neighborhood of market operation and separating small business from other businesses, Bates and Robb [9] 
found that firms that are concerned about crime are no less viable than other identical firms reporting that crime has no impact on their business. That finding suggests that firms do not take into account high crime in decision to operate in an area.

Rosenthal and Ross [10] analyzed the effects of crime on business location in five US cities. Combining crime data and business survey and assuming that land bids differ monotonically with violent crime, they found that while firms tend to disproportionately locate in high-crime areas, an increase in 100 violent crimes would reduce the retail share of employment by $22 \%$ and reduce the high-end share of local restaurants by 4.4 percentage points.

Krkoska and Robeck [11] investigate different aspects of victimization at the firm level in Europe and Asia, pointing out the effect of size, sector, sales growth, and business conduct as significant determinants of the likelihood of being targeted from both street crimes and organized crimes. Another major finding is that firms that spend a higher share of their sales on security services reinvest a lower share of their profit; suggesting that both direct (spending on security services) and indirect effects (perception of crime) negatively impact investment at the firm level. The study does not indicate the type of firms that are likely to suffer from crime, since paying for crime can be a management policy designed to improve the firm's performance. This is likely because the authors did not notice any problem of selection bias in the data used while they mention several limitations with the crime and business data.

The possibility of selection bias and endogeneity has been addressed by Greenbaum and Tita [12] in their analysis of the impact of increased violent crime on private sector in the United Sates. Using a difference-indifference approach on geographically disaggregated crime data across five American cities, the authors found that increased violence has the largest impact on slowing the creation of new retail businesses.

The studies that indicate either a positive or a negative effect of crime on business do not take into account the cost of self-protection and the direct cost of crime through decreased production. Asiedu [6] points to the role of legal system, institutions and political instability as determinants of foreign direct investment (FDI) to Africa and finds that efficient legal system and a good investment framework promote FDI while corruption and political instability hamper it. Of course, high crime rate in a country or state is a manifestation of institutional failure. Her result, while providing evidence on the role of instability and legal system on private investment inflows to Africa, does not analyze the effect of crime on the performance of firms that are already operating in the country nor does it indicate the sectors that are likely to be affected. Further, the paper does not address the mechanism through which institutions (or institutional failure) affects business activities.

The limitations of earlier studies are summarized by Gaviria [5] who indicate that corruption and crime substantially reduce competitiveness. The paper investigates the impact of perceived crime and corruption on sales and investment growth by comparing performance of firms in developing countries and those in OECD countries. This paper has a few limitations: First, it investigates the effects of perceived crime and corruption, not actual experience of crime since the impact of crime on business may be either direct (incidence of crime) or indirect (perceived crime). Second, comparing the performance of firms in the developing countries may not be the appropriate way to investigate the effects of crime on corporate behavior. Lastly, the work by Gaviria focused on Latin American while very little is known about the impact of crime on economic activities in the sub-Saharan Africa. Collier and Duponchel [7] found that the intensity of the civil conflict in Sierra Leone negatively affects labor skill accumulation at the firm.

Based on a theoretical approach borrowed from the shirking model, Azam and Langmoen [4] empirically investigated the determinants of thefts reporting at the manufacturing firm level in Cote d'Ivoire. They found that firms that use informal means for recruitment or do not pay or pay their workers less than market wages, are likely to report theft more frequently than others. This paper, while pinpointing criminal behavior and private enforcement of the law at the firm level, did not indicate the extent to which criminal activity affected business activity in general. Further, the conclusions of the paper reveal basically a human resource management issue (selecting honest workers) rather than showing how criminal activities impact the enterprise's growth.

Our work is not a commercial victimization analysis per se, as in Krkoska and Robeck [11], Rosenthal and Ross [10] or Azam and Langmoen [4]. Our research is different of these papers in three areas. First, it investigates the effects of crime on business as a consequence of institutional failure following a civil war and political instability. Second, it jointly assesses the effects of perceived crime and private protection on business activity. Lastly, since not all firms self-protect, our empirical approach accounts for self-selection into private protection.

This paper refers to commonly used performance indicators to assess the impact of crime. However, due to 
data limitations, we cannot use growth rate of economic outcomes as in Gaviria [5], Greenbaum and Tita [12] and Renders and Gaeremynck [13] and Rosenthal and Ross [10]. Rather, we assess the effect of crime on profitability using annual profit and firm level investment as measurements for firm's growth. According to Hax [14], using the profit (accounting profit) as performance indicator raises the issues of separation of periodsprofit is calculated for only a single period_-and the possibility of manipulation by the management, making it necessary to combine both profit (accounting) and market value as complementary measurement of performance. Still, profit serves to create incentives and appears to be a good indicator for our investigation. Indeed, stocks market is not as efficient in Cote d'Ivoire as it is worldwide and that our dataset is comprised of a large number of small businesses. Also, following Krkoska and Robeck [11], inflows of investment should be likely to assess the possible deterrent effect of crime on economic development. The later indicator should help to assess the microeconomic impact of governance on investment flows in a sub-Saharan African country, which approach is quite different from the work by Asiedu [6].

\section{Instability, Crime and Private Sector Trends in Cote d'Ivoire}

Cote d'Ivoire's economy is dominated by agriculture (mostly cocoa). A decade after independence in 1960, Cote d'Ivoire attempted structural transformation through massive shift from agricultural outputs to manufactured products. GDP growth rate averaged about 7\% per annum during this period. This relatively fast growth rate as powered by increased production and exports of cocoa and coffee.

However, during the 1980s, the international price of cocoa and coffee collapsed, thus beginning a long period of economic crisis including balance of payments crisis. As a consequence of the economic crisis and with the assistance of the International Monetary Fund (IMF) and the World Bank, Cote d'Ivoire started a series of reforms designed to enhance productivity, reestablish external equilibrium, and revitalize macroeconomic performance. An essential part of these reforms was the privatization of state owned enterprises (SOEs). The induced privatization led to the emergence of the private sector as the engine of economic growth. As a result the private sector contributed nearly two-thirds of GDP in the 1990s and this led to the creation of several formal sector modern jobs.

In 2008, the formal private sector consists for 24 industrial sectors according to the Standard Industrial Classification (SICs), making Cote d'Ivoire one of the most “industrialized” countries in West Africa. Chemicals and food processing account for 33\% and 28.5\% respectively of national industrial output. Even though economic growth was still driven by agriculture, private industry was changing the structure of the economy. Referring to the World Bank’s World Development Indicators, the annual growth rate of the value added by the industrial sector to the Ivorian economy grew substantially going from $-7.06 \%$ in 1990 , to $0.74 \%$ in 2000 and 4.5\% in 2010. Further, the preeminence of agriculture dropped from 32.5\% in 1990 to $24.22 \%$ in 2000 and $22.94 \%$ in 2010 while service's contribution to GDP, went from 44.33\% (1990) to 50.93\% (2000) and 49.67\% in (2010) while Manufacturing went from 20.9\% in 1990, 21.68\% in 2000 and 19.24\% in 2010.

The period of instability beginning in 1999, combined with excessive supply of light weapons stemming from the civil wars in neighboring countries such as Liberia and Sierra Leone dramatically increased the incidence of crime. In the city of Abidjan for instance, aggravated assaults and homicides, accounted for more than threequarters of crimes, leading to the widespread feeling of insecurity among urbanites [1]. Over the last two decades, the Ivorian Criminal Police reported that in the District of Abidjan, the rate of aggravated assaults for every 100,000 populations was respectively 17.42 in 1990, 169.43 in 2000 and 180.05 in 2007 while homicides rates increased significantly going from 2.61 in 1990 to 4.15 in 2000 and 6.09 in 2007.

The increase in insecurity resulted in increased country risk that caused a drop in the FDIs inflows. As evidenced by the World Bank’s World Development Indicators; FDIs inflows to Cote d'Ivoire dropped by 30\% between 2008 and 2010. The African Development Bank (2012) also pointed out that the insecurity induced by the Ivorian post-election war heavily affected the economy with the real GDP estimated to have dropped by 6\% in 2011, compared to an increase of 2.4\% (2010) and 3.8\% (2009).

The civil war led to a de-facto partition of the country into two where the government controlled the southern part and rebels controlled the northern part. The southern region, including the District of Abidjan, the cities of San-Pedro and Yamoussoukro, endowed with most of the natural resources (Cocoa, Gold, Oil,), is the location of most business activities. Given this division, the government could no longer efficiently provide public law enforcement and the resultant crime rates led companies to hire private security services to protect their 


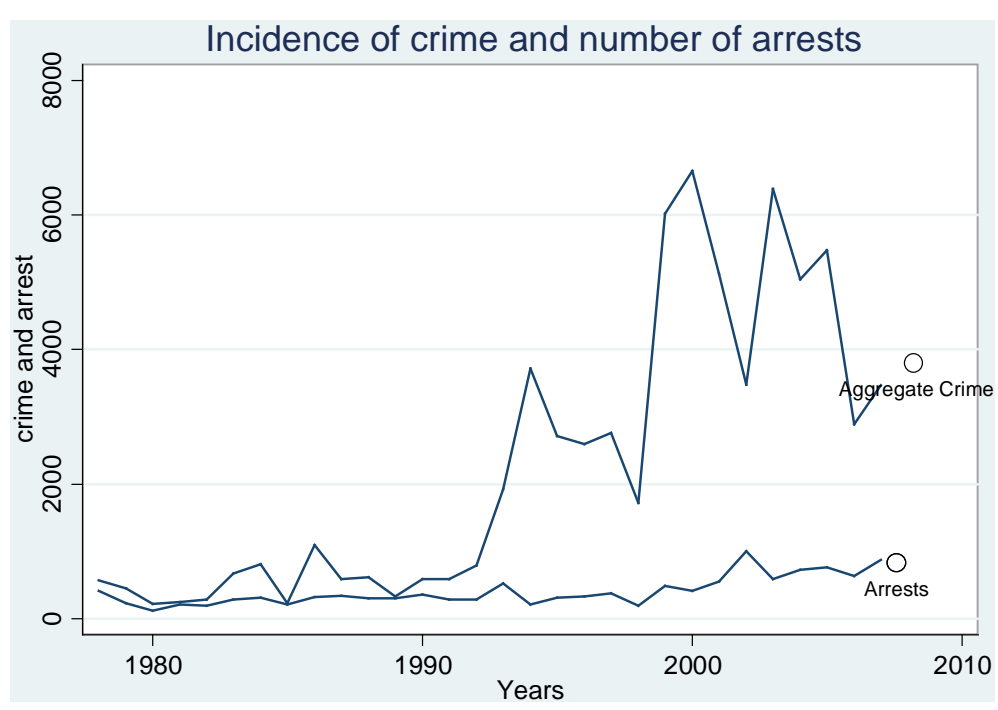

Figure 1. Incidence of crime and number of arrests.

Table 1. Summary statistics: average probability of arrest over the period 1978-2007.

\begin{tabular}{ccccc} 
& \multicolumn{2}{c}{ Period: 1978-2007 } & \multicolumn{2}{c}{ Conflict Period (1999-2007) } \\
\cline { 2 - 5 } & Mean (\%) & Std. Dev. & Mean (\%) & Std. Dev. \\
\hline Homicides & 71.0664 & 39.6261 & 58.2325 & 28.2937 \\
Assaults & 31.9685 & 30.7451 & 6.7824 & 4.9985 \\
Aggregate crime & 36.5770 & 26.4797 & 15.3902 & 8.0162 \\
\hline
\end{tabular}

businesses (see Figure 1).

Table 1 presents the average probabilities of arrest of crimes reported to the police. Except homicides (71\%), approximately $30 \%$ of crime reported to the Police is cleared (31\% for assaults and $36 \%$ for aggregate crimes). The probabilities of apprehension dropped dramatically during the instability period (marked by the military coup d'état of 1999 and the 2002 rebellion). Indeed, on the average, only 7\% and 15\% of assaults and aggregate crime reported to the Police led to an arrest, exhibiting therefore the inefficiency of the police resources.

As a consequence, between 2005 and 2008 for instance, the number of private security enterprises increased by $300 \%$ with an estimated average annual turnover of 500 million dollars presumably in response to increased demand for protection. In 2009, there was an estimated private security companies (PSC) personal of 50,000 while the national police officers approximated 32,000 indicating a ratio of 260 PSC per 100,000 versus a ratio of 166 police officers per 100,000 [15].

\section{Model, Data, and Estimation Method}

This part of the research presents the model, the data and the econometric strategy used to test empirically the linkage between crimes and business activities.

\subsection{The Model}

We use a simple but modified model of profit maximization to analyze the effects of crime on private business in Cote d'Ivoire. We assume that private sector businesses maximize profit subject to a technology constraint. We assume that these businesses take input and output prices as given. Output positively depends on the quantity and quality of traditional inputs of capital $(K)$ and labor $(L)$ as well as the level of safety $(S)$ in the community. We define safety to mean the absence or low levels of crime, that is $S=s$ (Crime), $s_{\text {crime }}<0$. An increase in crime decreases safety hence reduces output, all things equal. The production technology is given as: 


$$
Q_{i} f(K, L, S) \quad f_{K}, f_{L}, f_{S}>0
$$

There are several reasons why safety can be considered a productive input in a post-conflict country with high crime rates and ineffective judiciary. Businesses need a minimum level of safety within which to operate. Without this safety, labor, capital and management are not safe and may not be available at prevailing wages. Even when businesses get these inputs, production can be disrupted by criminal gangs or output, input, and finances are likely to be stolen from production and sales facilities.

Safety has to be produced with labor and other inputs either by the public sector or by the private sector at a cost to businesses. Since safety is a pubic good, a minimum level of safety as indicated by a maximum level of crime acceptable to businesses and society $(\hat{C})$ has to be provided by the public. When the level of crime is higher (level of safety is lower) than what is acceptable to business, business will then have to invest in self-protection in order to bring safety up (crime down) to the level that is acceptable. The level of safety depends on the level of safety provided through the public sector and the additional safety provided by the private sector. The total level of safety therefore depends on the level of safety provided by the public and the additional safety provided through self-protection. Formally,

$$
S=S\left(S_{p}, \hat{C}\right), \quad S_{S_{p}}>0, S \hat{C}<0
$$

We note that businesses will invest in self-protection if public protection leads to crime rate that is over and above the maximum crime rate that business deem acceptable, $S_{p}$. Therefore $S_{p}$ is positively related to the differential between the actual crime rate $(C)$ and the maximum rate acceptable to businesses $(\hat{C})$. The relationship between crime rate and private self-protection is given as $S_{p}=g(C-\hat{C}), g^{\prime}>0$. Given $\hat{C}$, an increase in crime rate leads to an increase in self-protection expenditure, all things equal.

Given the prices of output and inputs and production technology, the firm chooses the level of labor, capital, and safety to maximize profit given as:

$$
\pi=p Q(K, L, S)-r K-\omega L-P_{s} S
$$

where $p, r, w$, and $p_{s}$ are output price, rental rate of capital, wage rate, and the cost of safety.

These input prices are assumed fixed for the firm even though they may change with increased aggregate demand or supply of these inputs.

Safety has two opposing effects on profits. On the one hand, increased safety increases output but like any normal input, it also increases the cost of production. The first order conditions indicate that firms will continue to increase the input of safety up to the point where the marginal revenue product of safety equals the marginal cost of safety. Safety is generally not measurable but can be inferred from the crime rate. Here one can measure the dynamics of the effects of safety on output through the dynamics of the effects of crime on output.

An increase in crime affects the firms profit in two different ways-through a reduction in output and an increase in the cost of provision of self-protection. This relationship is given as:

$$
\partial \Pi / \partial C=p \partial Q / \partial S * \partial S / \partial C-P_{S}\left(1+\partial S / \partial S_{p} * \partial S_{p} / \partial C\right) .
$$

An increase in crime rate decreases the profit by decreasing the marginal value product (first expression on the right hand side (RHS)) while increasing the marginal cost of safety provision (the second expression on the RHS). This suggests that the profit maximizing output is lower with higher crime rate than with low crime rate, all things equal.

From the discussion above, we can derive several measures of firms performance as implicit functions of crime and other control variables. For example, we can derive the firm's profit as a function of input prices, crime rate, and level of output or we can derive the level of output as a function of input quantities and crime rate; similar arguments can be made for capacity utilization or labor demand by firms. To sum up, we can write the firm's performance generally as:

$$
Q_{i}=q(\text { Crime, } X)
$$

where $Q_{i}$ is outcome $i$ of the form, $X$ is a vector of conditioning variables and crimes is as defined above. The elements contained in the $X$ vector include educational attainment of management, location, ownership structure 
of enterprise, size of enterprise, and input prices. Elements of $X$ that will be contained in a particular equation will depend on the outcome being investigated since not all variables may be relevant for all outcomes. In general, we expect crime to have a negative impact on outcome $i$, all things equal.

We have written Equation (4) in a general form without specifying a functional form. Economic theory does not provide us with a specific functional form; hence we choose to specify a simple linear functional form of the equation we estimate. The equation we estimate is given as:

$$
\left.Y_{i}=\alpha_{0}+\alpha_{1} \text { (Crime) }+\alpha_{2} \text { (Self-protection }\right)+\left(X^{\prime}\right) \beta+\varepsilon_{i}
$$

where $Y_{i}$ is firm outcomes, crime denotes perceived crime; self-protection is firm's provision for

Security $\alpha$ and $\beta$ are coefficients to be estimated is $\varepsilon_{i}$ a stochastic error term and all other variables are defined in the text above.

\subsection{Data}

The data used to investigate the effects of crime rate on business growth in this paper are from enterprise survey conducted by the World Bank in Cote d'Ivoire from 26 October 2008 to 20 February 2009. The survey was designed to provide information on the constraints to private sector growth and to capture the business environment in the country. The survey targeted mainly non-agricultural sector, manufacturing, construction, services, and transport, storage and communication and was conducted in three cities.

The sample for registered establishments in Ivory Coast was selected using stratified random sampling. Three levels of stratification were used: sector, size, and geographic region. Industry stratification was designed taking into account three manufacturing industries (food, textiles, and other), one services industry (retail) and one residual sector. The sample targeting initially 240 manufactures and 120 services industries and residual categories, was then adjusted to reflect the accurate prevalence of manufacturing establishments in Ivory Coast.

Size stratification was defined following the SICs, namely: micro (1 to 4 employees), small (5 to 19 employees), medium (20 to 99 employees), and large (more than 99 employees). Regional stratification was defined in terms of the geographic regions with the largest commercial presence in the country: Abidjan, San Pedro, and Yamoussoukro were the three metropolitan areas selected, excluding Bouake (largest north-central city controlled by the rebellion). The three cities-Abidjan, Yamoussoukro and San-Pedro-are where business activities predominant in Cote d'Ivoire and are located in the southern region, a region under the government control.

Besides standard business characteristics such as industry branch, firm size and ownership, questions were asked about multiple aspects of business regulation, crime, disorders and other matters that affect business operations. This is an important source of information useful to make the investigation of interest. Specifically, the data encompasses firm's appraisal with respect to the followings: the perception of crime as a constraint to business, the propensity to pay for private security, the experience of losses due to crime and violence and the total annual value of losses caused by crime.

The problems with survey data are well known and are not uncommon to Cote d'Ivoire. For instance, many owners or managers of small-scale companies have serious book keeping problems hence, they have not given accurate figures on finance and costs related questions. However, nothing indicates that large firms were also telling the truth and giving accurate source of information. Also, the serious political crisis and general sense of lawlessness since 1999, may have contributed to inaccurate source of information; making it difficult to undertake such a survey. Despite these limitations, World Bank data are the only data collected on business activities at the enterprise level in Cote d'Ivoire in recent years. Table 2 presents the descriptive statistics of variables used in the sample of 526 observations.

$69 \%$ of the sample is small firms and 22\% large firms. A large proportion of businessmen interviewed are sole proprietors (71\%) and only $16 \%$ are foreign-owned. A large proportion of owners are relatively well educated with $43 \%$ having a secondary school degree and $30 \%$ having university degree or higher. $39 \%$ are retail enterprise, $20 \%$ are other manufacturing enterprises and $39 \%$ are service enterprises. $44 \%$ of firms pay for security.

It appears that there is a significant relationship between firm size and private provision of security. Indeed, 80\% of firms that do not pay for security are small businesses while $30 \%$ of medium-size businesses and $16 \%$ of large companies pay for security. There is also a significant difference in ownership status with $26 \%$ of foreign owned firms paying for security. Most of domestic private firms do not pay for self-protection as shown by the significant difference between the two means group. Meanwhile, difference in education level seems matter for firms 
Table 2. Summary statistics.

\begin{tabular}{|c|c|c|c|c|}
\hline Variable & Mean $^{+}$ & Self-protection (a) & No self-protection (b) & Mean difference $^{++}(\mathrm{b}-\mathrm{a})$ \\
\hline \multicolumn{5}{|l|}{ Firm characteristics } \\
\hline Retailers (\%) & 0.2357 & 0.2478 & 0.2260 & -0.0218 \\
\hline Service (\%) & 0.3859 & 0.4059 & 0.3698 & -0.0361 \\
\hline Food and plastics (\% & 0.0817 & 0.1068 & 0.0616 & $-0.0451^{*}$ \\
\hline Textile (\%) & 0.0931 & 0.0341 & 0.1404 & $0.1062^{* * *}$ \\
\hline Other manufactures (\%) & 0.2015 & 0.2051 & 0.1986 & -0.0064 \\
\hline Small (\%) & 0.6882 & 0.5470 & 0.8013 & $0.2543^{* * * *}$ \\
\hline Medium (\%) & 0.2319 & 0.2905 & 0.1849 & $-0.105^{* * *}$ \\
\hline Large (\%) & 0.0799 & 0.1623 & 0.0136 & $-0.148^{* * *}$ \\
\hline Sole proprietorship (\%) & 0.7186 & 0.5641 & 0.8424 & $0.2783^{* * * *}$ \\
\hline Domestic (\%) & 0.7129 & 0.6196 & 0.7876 & $0.1680^{* * *}$ \\
\hline Foreign (\%) & 0.1596 & 0.2564 & 0.0821 & $-0.1742^{* * *}$ \\
\hline Public (\%) & 0.1197 & 0.1154 & 0.1232 & 0.0079 \\
\hline Sales & $2.23 e+09$ & $4.76 \mathrm{e}+09$ & $2.07 e+08$ & $-4.55 e+09^{* *}$ \\
\hline Profit & $1.10 \mathrm{e}+09$ & $2.40 \mathrm{e}+09$ & $6.41 \mathrm{e}+07$ & $-2.34 \mathrm{e}+09^{* * *}$ \\
\hline Volume of investment & $2.94 \mathrm{e}+07$ & $5.63 e+07$ & 7859095 & $-4.84 \mathrm{e}+07^{* * *}$ \\
\hline Located in export area (\%) & 0.1939 & 0.3247 & 0.0890 & $-0.2357^{* * *}$ \\
\hline \multicolumn{5}{|l|}{ Manager's characteristics } \\
\hline Higher Education (\%) & 0.2984 & 0.4230 & 0.1986 & $-0.2244^{* * *}$ \\
\hline Secondary Education (\%) & 0.4334 & 0.3589 & 0.4931 & $0.1341^{* *}$ \\
\hline Primary Education (\%) & 0.1311 & 0.1068 & 0.1506 & 0.0438 \\
\hline No education & 0.1026 & 0.0555 & 0.1404 & $0.0848^{* * *}$ \\
\hline Manager’s experience (years) & 12.129 & 14.341 & 10.356 & $-3.985^{* * * *}$ \\
\hline \multicolumn{5}{|l|}{ Crime and disorder } \\
\hline Crime a severe obstacle (\%) & 0.3269 & 0.3504 & 0.3082 & -0.0422 \\
\hline Crime a major obstacle (\%) & 0.2224 & 0.3119 & 0.1506 & $-0.1612^{* * *}$ \\
\hline Crime a moderate obstacle (\%) & 0.1254 & 0.1196 & 0.1301 & 0.0104 \\
\hline Crime a minor obstacle (\%) & 0.1996 & 0.1581 & 0.2328 & $0.0747^{*}$ \\
\hline Victim of loss due to crime (\%) & 0.2509 & 0.3632 & 0.1609 & $-0.2023^{* * *}$ \\
\hline Operating after beginning of civil (2002) & 0.5855 & 0.4572 & 0.6883 & $0.2310^{* * *}$ \\
\hline Operating after 2004 riots & 0.4562 & 0.3162 & 0.5684 & $0.2522^{* * *}$ \\
\hline Paying for security (\%) & 0.4448 & - & - & - \\
\hline Number of observations & 526 & 234 & 292 & \\
\hline
\end{tabular}

$(+)$ These are unweighted averages; $++(*),\left({ }^{* *}\right),\left({ }^{* * *}\right)$ significant difference respectively at $10 \%, 5 \%$ and $1 \%$. 
paying for security and firms that do not. $42 \%$ of firms with higher educated top-managers pay for security while only $10 \%$ of firms whose management had only primary education provide self-protection. Self-protection is also positively correlated with location in an industrial zone. 32\% of firms located in industrial zone pay for self protection while only $9 \%$ providing self-security are located outside industrial zones.

Lastly, $33 \%$ and $22 \%$ of firms consider crime and disorder respectively as a severe and major obstacle to doing business in Cote d'Ivoire. While only $15 \%$ of businesses not paying for security consider crime to be a major impediment to their activities, approximately $31 \%$ of those paying for self-protection believe crime to be a major constraint to the expansion of their businesses. The difference is statistically significant. Besides, a large proportion of businesses that experience losses (36\%) pays for self-protection. This difference is statistically significant. Operating after the civil war in 2002 and the 2004 riots against the private sector outlines self-protection. Indeed, with a statistically significant difference, $68 \%$ and $56 \%$ of firms operating respectively after the civil war and the riots do not pay for security.

The data description above delineates some significant differences between firms that offer self-protection and those that do not and this may help to determine the decision for self-protection.

\subsection{Estimation Method}

Crime affects business through two possible channels: directly by decreasing production and indirectly through the cost of self-protection. Self-protection may be endogenous since firms that care about their productivity and performance may choose to self-protect. These firms may also be the firms that can afford to finance self-protection. To assess the impact of crime and insecurity on business sector, our econometric design methodology accounts for selection into self-protection. According to Greenbaum and Tita [12], business survey data very often exhibit selection bias and endogeneity. We use the Heckman two-step procedure to correct for that selection.

The effect of crime in this study is captured through the demand of self-protection by firms. The decision variable is a binary one (paying for security or not). Following Wooldridge [16], variable is defined as follows:

$$
d_{i}=\left\{\begin{array}{l}
1, \text { if pays for security } \\
0 \text { otherwise }
\end{array}\right.
$$

The output variable $y$ is a continuous one and is observed for firms paying for security and for those that do not. Denote $X$ the matrix of observable characteristics of firms. According to Renders and Gaeremynck [13] and Bates and Robb [9], those business characteristics include: size, location, industry and top manager's characteristics and his experience with crime. Our outcomes variables are the profit and the volume of investment.

Also, as indicated by Rosenthal and Ross [10], the endogeneous nature of self-protection as a measurement of crime is associated to the fact that economic activity may cause attractiveness to crime because of higher rate of returns or the impact of crime on firm's cost function differ from firm to firm.

In the first step, we estimate a reduced form capturing selection into self-protect (probit model) using Maximum Likelihood method; we then calculate the inverse Mills' ratio using the predicted value from the regression. In the second stage, the outcome equation is estimated using OLS. One of the issues associated with the Heckman sample selection model is that the asymptotic sampling distribution may be very difficult to derive [16]. To produce better approximation of standard errors and increase bias correction, we use the method of bootstrap method with 500 replications.

\section{Empirical Results}

This section presents the results for self-protection and business performance. The first sub-section discusses the estimates for the probability of self-protection while the second sub-section discusses the effects of self-protection on business performance.

\subsection{The Selection for Self-Protection}

Table 3 presents the results from the first step regression (probit model) tackling the likelihood to pay for security. Our model specification assumes that the firm's likelihood for self-protection is associated with the size, location, the top manager's education, the date of operation, the level of sales, perceived crime and experience with crime. 
Table 3. Probit model on self-protection.

\begin{tabular}{ccccc}
\hline Dependent Variables $^{+}$ & Coefficient $^{++}$ & Robust Std. Error & $\mathbf{Z}$ & Marginal Effects \\
\hline Higher Education & $0.4167^{* *}$ & 0.1371 & 3.04 & 0.1649 \\
Log sales & $0.03262^{*}$ & 0.0190 & 1.71 & 0.0129 \\
Small firm & $-0.2595^{*}$ & 0.1436 & -1.81 & -0.1029 \\
Large firm & $0.6129^{*}$ & 0.3283 & 1.87 & 0.2387 \\
Located in export area & $0.4929^{* *}$ & 0.1664 & 2.96 & -0.1626 \\
Operated after 2004 & $-0.4148^{* * *}$ & 0.1238 & -3.35 & 0.1579 \\
Crime severe obstacle & $0.3991^{*}$ & 0.1617 & 2.47 & 0.2135 \\
Crime major obstacle & $0.5420^{* *}$ & 0.1793 & 3.02 & -0.0164 \\
Crime minor obstacle & -0.0417 & 0.1873 & -0.22 & 0.1117 \\
Experience loss & $0.2813^{*}$ & 0.1464 & 1.92 & -294.30 \\
Log Likelihood & & & 96.10 & 0.1856 \\
Wald chi2(10) & & & $\mathbf{5 2 6}$
\end{tabular}

+: Dependent variable $=1$. If firm pays for security; Base: medium firm, primary education, shared business, publicly owned, crime moderate obstacle, other manufactures. $++\left({ }^{*}\right),\left(\left(^{* *}\right),\left(^{* * *}\right)\right.$ are significant coefficients respectively at $10 \%, 5 \%$ and $1 \%$.

We found a significant relationship between the likelihood for self-protection and firm size, suggesting that size is a significant determinant to hire private security. While small businesses are unlikely to pay for security, large firms are. A discrete from not being a large business to being a large one increases the probability to paying for self-protection by 24 percentage points.

Education seems also positively and significantly associated with the likelihood to self-protect. A discrete change from a non-educated top manager to a top manager graduating from college raises the probability to selfprotect by 16.5 percentage points. This finding seems consistent with many empirical works highlighting the role of education, as in Gaviria and Pages [17], Barslund et al. [18] and Kimou [1]. This result is consistent with the human capital effect of crime.

There is a positive and significant relationship between the logarithm of annual sales and the likelihood to self-protect. A $1 \%$ change in annual sales raises the probability of paying for private security by 1.3 percentage points. This is consistent with Rizzo [19]. The expected returns to crime should be higher the more firms perform.

The probability of self-protection is also significantly and positively related to location in an export or industrial area. The change of location from non industrial zone to an industrial or export zone increases the probability to self-protect by 19.46 percentage points. This finding is also in accordance with the works by Greenbaum and Engberg [20], Felson and Clark [21] and Matheson and Baade [22], emphasizing cost sharing opportunities associated with location in export area.

Perceived crime, another measurement of crime, is significantly and negatively associated with the likelihood for self-protection. Firms that perceive crime respectively major and severe constraint to doing business are likely to pay for security. A discrete change from perceiving crime as minor obstacle to perceiving crime as a major and a severe constraint to doing business increases the likelihood to self-protect respectively by 21.35 and 15.79 percentage points. Also, there is a negative and significant relationship between operating after the violence of 2004 and the probability to pay for private security. A change from not perceiving crime as an obstacle to doing business to perceiving crime as a serious obstacle to doing business in Cote d'Ivoire reduces the likelihood to self-protect by 11.5 percentage points. This result is corroborated by the experience to crime.

Also operating after 2004 reduces the probability to pay for self-protection by 16.26. This coefficient estimate which is unexpected could tentatively be explained. First, data collection bias: this unusual violent crime goes 
back the occurrence of conflicts in neighboring countries of Liberia and Sierra Leone (in the 1990s) and the military coup d'état and civil war (early 2000s) in Cote d'Ivoire, while the survey was being conducted in 2009. Existing firms may have already included instability in their decision. Also, 69\% of the observations in our sample are small businesses that cannot afford private protection and may have already factored insecurity into their behavior. Lastly, after the violent riots against the private sector in 2004, the government initiated many programs for the private sector including tax reduction, and special security measures to encourage firms to stay while attracting prospective investors as well. It is also possible that these firms had not yet been victims of crime, hence did not have the need to self-protect.

This last explanation seems to be confirmed by the variable capturing experience with crime. There is a positive and significant relationship between the likelihood to self-protect and loss associated with crime, violence and disorder. A discrete change from not losing-to-losing stuffs due to crime, violence and disorder increases the likelihood to hire a private security company by 11 percentage points.

\subsection{Correction for Selection Bias}

We first run an OLS regression as a benchmark model designed under the assumptions that self-protection is exogenous to firm's growth. Neither the dummy describing the payment of private security nor the perceived crime variables are significant. These estimates may suggest that our model exhibits a selection bias. Paying for security may be affected by unobserved characteristics.

The selection bias problem is corrected using the Heckman's two-steps procedures. According to Sartori [23], if we can find at least one explanatory variable that affect the selection, but not in the outcome equation, our estimation technique will be good. In our empirical design we postulate that the variable "experience loss due to crime" significantly impact decision into self-protection while not affecting firms' profitability and investment.

We run the Heckman two-steps using "experience loss due to crime" as exclusion restriction in the profitability model. In the investment model in addiction to "experience loss due to crime", the second stage regression has been conducted with selected variables likely to explain flow of investment.

The results for the profitability equation are presented in Table 4. The inverse Mill's ratio is significant and

Table 4. Two-step regression: crime and profitability.

\begin{tabular}{cccc}
\hline Log Profit+ & Coefficient & Boot. Std. Dev. & $Z$ \\
\hline Higher education & -0.4838 & 0.3690 & -1.31 \\
Manager's experience (squared) & -0.0004 & 0.0003 & -1.23 \\
Log sales & 0.7777 & 0.1526 & $5.09^{* * *}$ \\
Small firm & 0.3140 & 0.2437 & -0.66 \\
Large firm & -0.5312 & 0.7996 & $1.77^{*}$ \\
Operated after 2004 & 0.58901 & 0.3321 & -1.09 \\
Located in export area & -0.4540 & 0.4180 & $-2.14^{* *}$ \\
Crime severe obstacle & -0.8519 & 0.4895 & $-2.25^{* *}$ \\
Crime major obstacle & -1.0453 & 0.3789 & 1.39 \\
Crime minor obstacle & 0.1816 & 0.1306 & $-2.45^{* * *}$ \\
Inverse Mill's ratio & -2.8291 & 1.1565 & 5.44 \\
Constant & 6.0163 & 1.1062 & \\
R-squared & 0.7939 & & \\
Adjusted R-squared & 0.7885 & & \\
Wald chi2 (11) & 1863.69 & & \\
Number of observations & 435 & &
\end{tabular}

+: Dependent variable: annual profit; Exclusion: past experience with loss due to crime and disorder. Bootstrap: results after 500 replications. $++\left(^{*}\right)$, $\left({ }^{* *}\right),\left({ }^{* * *}\right)$ are significance respectively at $10 \%, 5 \%$ and $1 \%$. 
Table 5. Two-step estimation: crime and Investment.

\begin{tabular}{cccc}
\hline Log Investment + & Coefficient & Boot. Std. Dev. & $Z$ \\
\hline Higher education & 0.1850 & 0.3244 & 0.57 \\
Log sales & 0.1739 & 0.1040 & $-1.67^{*}$ \\
Small firm & -0.7566 & 0.4171 & 0.86 \\
Large firm & 0.4389 & 0.5077 & -0.94 \\
Crime severe obstacle & -0.4095 & 0.4357 & 0.25 \\
Crime major obstacle & 0.1220 & 0.4875 & 0.41 \\
Crime minor obstacle & 0.1734 & 0.4267 & $-3.06^{* *}$ \\
Inverse Mill's ratio & -2.1489 & 0.7031 & 6.25 \\
Constant & 14.3611 & 2.2977 & \\
R-squared & 0.4821 & & \\
Adjusted R-squared & 0.4599 & & \\
Wald chi2 (8) & 206.34 & 195 &
\end{tabular}

+: Dependent variable: logarithm investment; Exclusion: past experience with Loss due to crime and disorder, location and operation after 2004. Bootstrap: results after 500 replications; $++\left({ }^{*}\right),\left(\left(^{* * *}\right),\left({ }^{* * *}\right)\right.$ are significance respectively at $10 \%, 5 \%$ and $1 \%$.

negatively signed suggesting that the error terms in the selection and primary equations are negatively correlated. There are some unobserved characteristics that increase the probability of paying for security (or not paying for security) with a negative impact on profitability. The two measurements of crime negatively affect firm performance. Perceived crime (major and severe obstacle) and "payment for security" affect negatively and significantly firms' profit. This finding is consistent with Gaviria [5] who conclude that the adverse effect of crime on poor firm performance may be explained by increased costs and low competitiveness.

From this result another question emerges: if crime prevents to build profitable business in a context of instability, what is its effect on investment at the firm level?

The results from the investment regression (see Table 5) give a clue to that question.

Like in the profit regression, the inverse Mill's ratio is significant in the overall equation. The unobserved characteristics that affect the likelihood to self-protect have a negative impact on investment. These findings suggest that self-protection that is basically intended to maintain existing capacity production actually tends to reduce firm competitiveness. Hence, increased crime rate combined with poor enforcement of the law, not only affect firms' short term performance (profit) but also long-term decision (investment) as well. It seems that in the context of political turmoil, businesses are likely to postpone their investment decisions for a more reliable business environment due to impeding costs of crime and disorder.

\section{Conclusions}

This paper was a contribution to the understanding of the microeconomic impacts of increased crime in Cote d'Ivoire. Specifically, the paper investigated the effects of crime and violence on the development of the private sector. We tested the impacts of crime and the generated self-protection on firm's profitability and capital accumulation. Theoretically, the economic consequence of crime on business was to be determined: either positively due to likely weak competition and readily available cheaper labor force or negatively consecutive to additional costs imposed by high crime incidence.

We tested these theoretical predictions using a Heckman two-step procedure. The two-step methodology pointed out that self-protection exhibited a selection problem. To deal with issues of identification and potentially biased standard errors pertaining to the Heckman selection model, past experience with loss caused by 
crime had been used as exclusion restriction and while bootstrapping the second stage regression with 500 replications.

We found that selection for self-protection was significantly and positively related to sales, location in an industrial area and loss due to crime previously encountered; while negatively affected by perceived crime. These findings suggested that firms with large assets, which had been affected by crime, were likely to pay for security. Private security provision was costly and was only made affordable to firms that had large assets. Small firms could not afford private protection, although perceiving crime and violence as serious obstacles to do business.

As far as the effects of perceived crime and self-protection on economic outcomes were concerned, we found that self-protection induced by high incidence of crime reduced the profit of contracting firms, suggesting that there was a negative return from private policing at the firm level. We also found that crime through self-protection was negatively and significantly related to private investment. The surges in violence seriously harmed businesses through perceived crime and incidence of crime as well.

From these results, we recommended the implementation of a security policy involving all stakeholders including the private sector. For example, a policy should aim at reducing the security threat and reducing the perceived country risk by corporate and prospective entrepreneurs. Security reforms could be implemented along with some specific incentives (tax or employment incentives for instance) towards the industries that had been deeply affected by crime and violence; particularly small business.

\section{References}

[1] Kimou, J.C.A. (2012) Economic Conditions, Enforcement and Criminal Activities in the District of Abidjan. International Tax and Public Finance, 19, 913-941. http://dx.doi.org/10.1007/s10797-010-9145-9

[2] Demombynes, G. and Zler, B. (2005) Crime and Local Inequality in South Africa. Journal of Development, 76, 265292. http://dx.doi.org/10.1016/j.jdeveco.2003.12.015

[3] Fafchamps, M. and Minten, B. (2006) Crime, Transitory Poverty and Isolation: Evidence from Madagascar. Economic Development and Cultural Change, 54, 579-603. http://dx.doi.org/10.1086/500028

[4] Azam, J.P. and Langmoen, M. (2001) Reported Theft in Ivorian Manufacturing Firms. ARQAD Working Paper.

[5] Gaviria, A. (2002) Assessing the Effects of Corruption and Crime on Firm Performance: Evidence from Latin America. Emerging Markets Review, 3, 245-226. http://dx.doi.org/10.1016/S1566-0141(02)00024-9

[6] Asiedu, E. (2005) Foreign Direct Investment in Africa: The Role of Natural Resources, Market Size, Government Policy, Institutions and Political Stability. WIDER Research Paper No. 2005/24.

[7] Collier, P. and Duponchel, M. (2010) The Economic Legacy of Civil War: Firm Level Evidencefrom Sierra Leone, UNU-WIDER Working Paper 2010/90.

[8] World Bank (1997) Uncertainty, Instability and Irreversible Investment: Theory, Evidence and Lessons for Africa. Working Paper, World Bank, Washington DC.

[9] Bates, T. and Robb, A. (2008) Crime’s Impact on the Survival Prospects of Young Urban Small Businesses. Economic Development Quarterly, 22, 228. http://dx.doi.org/10.1177/0891242408321255

[10] Rosenthal, S. and Ross, A. (2010) Violent Crime, Entrepreneurship and Cities. Journal of Urban Economics, 67, 135149. http://dx.doi.org/10.1016/j.jue.2009.09.001

[11] Krkoska, L. and Robeck, K. (2009) Crime, Business Conduct and Investment Decisions: Enterprise Survey Evidence from 34 Countries in Europe and Asia. Review of Law and Economics, 5, 493-515. http://dx.doi.org/10.2202/1555-5879.1299

[12] Greenbaum, R. and Tita, G. (2004) The Impact of Violence Surges on Neighborhood Business Activity. Urban Studies, 41, 2495-2514. http://dx.doi.org/10.1080/0042098042000294538

[13] Renders, A., Gaeremynck, A. and Sercu, P. (2010) Corporate-Governance Ratings and Company Performance: A Cross-European Study. Corporate Governance: An International Review, 18, 87-106. http://dx.doi.org/10.1111/j.1467-8683.2010.00791.x

[14] Hax, H. (2003) Measuring the Firm’s Performance: Accounting Profit versus Market Value. Journal of International and Theoretical Economics (JITE), 159, 675-682. http://dx.doi.org/10.1628/0932456032584586

[15] The Small Arms Survey (2011) The Small Arms Survey 2011: States of Security. Annual Report, Geneva.

[16] Wooldridge (2002) Econometric Analysis of Cross Section and Panel Data. The MIT Press, Cambridge, MA and London. (Chapter 18.1-18.4)

[17] Gaviria, A. and Pages, C. (2002) Patterns of Crime Victimization in Latin American Cities. Journal of Development 
Economics, 67, 181-203. http://dx.doi.org/10.1016/S0304-3878(01)00183-3

[18] Barslund, M., Rand, J., Tarp, F. and Chiconela, J. (2007) Understanding Victimization: The Case of Mozambique. World Development, 35, 1237-1258.

[19] Rizzo, M. (1979) The Cost of Crime Victimization: An Empirical Analysis. The Journal of Legal Studies, 8, 177-205. http://dx.doi.org/10.1086/467606

[20] Greenbaum, R.T. and Engberg, J.B. (2004) The Impact of State Enterprise Zones on Urban Manufacturing Establishments. Journal of Policy Analysis and Management, 23, 315-339. http://dx.doi.org/10.1002/pam.20006

[21] Felson, M. and Clark, R.V. (1997) Business and Crime Prevention. Willow Tree Press, Monsey.

[22] Matheson, V. and Baade, R.A. (2004) Race and Riots: A Note on the Economic Impact of the Rodney King Riots. Urban Studies, 41, 2691-2696. http://dx.doi.org/10.1080/0042098042000294628

[23] Sartori, A.E. (2003) An Estimator for Some Binary-Outcome Selection Models without Exclusion Restrictions. Political Analysis, 11, 111-138. 